\title{
Evaluation of Mutagenicity of Covid-19 Virus and the effect of Morphine in its Treatment
}

\section{Ali Khanifar}

Kurdistan University of Medical Sciences

Corresponding Author: Ali Khanifar, Master of Medical Microbiology.

Received Date: November 11, 2021; Accepted Date: November 24 2021; Published Date: November 30,2021

Citation: Ali Khanifar. (2021). Evaluation of Mutagenicity of Covid-19 Virus and the effect of Morphine in its Treatment. J. Immunology and Inflammation Diseases Therapy. 4(1); Doi:10.31579/2637-8876/022

Copyright: () 2021 Ali Khanifar. This is an open-access article distributed under the terms of The Creative Commons Attribution License, which permits unrestricted use, distribution, and reproduction in any medium, provided the original author and source are credited.

\begin{abstract}
:
Because the covid-19 virus is amazingly mutating, we urgently need a lot of articles in this area. In light of recent events, we have been writing an article on the mutagenicity of the covid-19 virus and treatment with morphine. The covid-19 virus is an exception due to its non-segmented genome, its mutagenicity. Also in this article morphine is a suitable drug because it neutralizes most of the symptoms of the covid-19 virus. Morphine increases immunity against the virus due to the presence of mu3 receptors on the surface of immune cells. Morphine also counteracts symptoms such as shortness of breath, pain, and even diarrhea. Diarrhea has been reported in cases of the covid-19 virus.

Keywords : morphine-covid 19; mutagenicity
\end{abstract}

\section{Introduction :}

Coronavirus $(\mathrm{CoV})$ means a crown, which is taken from the Latin word corona. Coronavirus leads to a wide spectrum of human respiratory tract infections Variable from a mild cold to intense respiratory distress syndrome. Because the Covid 19 virus is present in the coronavirus family, which includes viruses with a single-stranded, positive-strand RNA genome ( Figure 1).

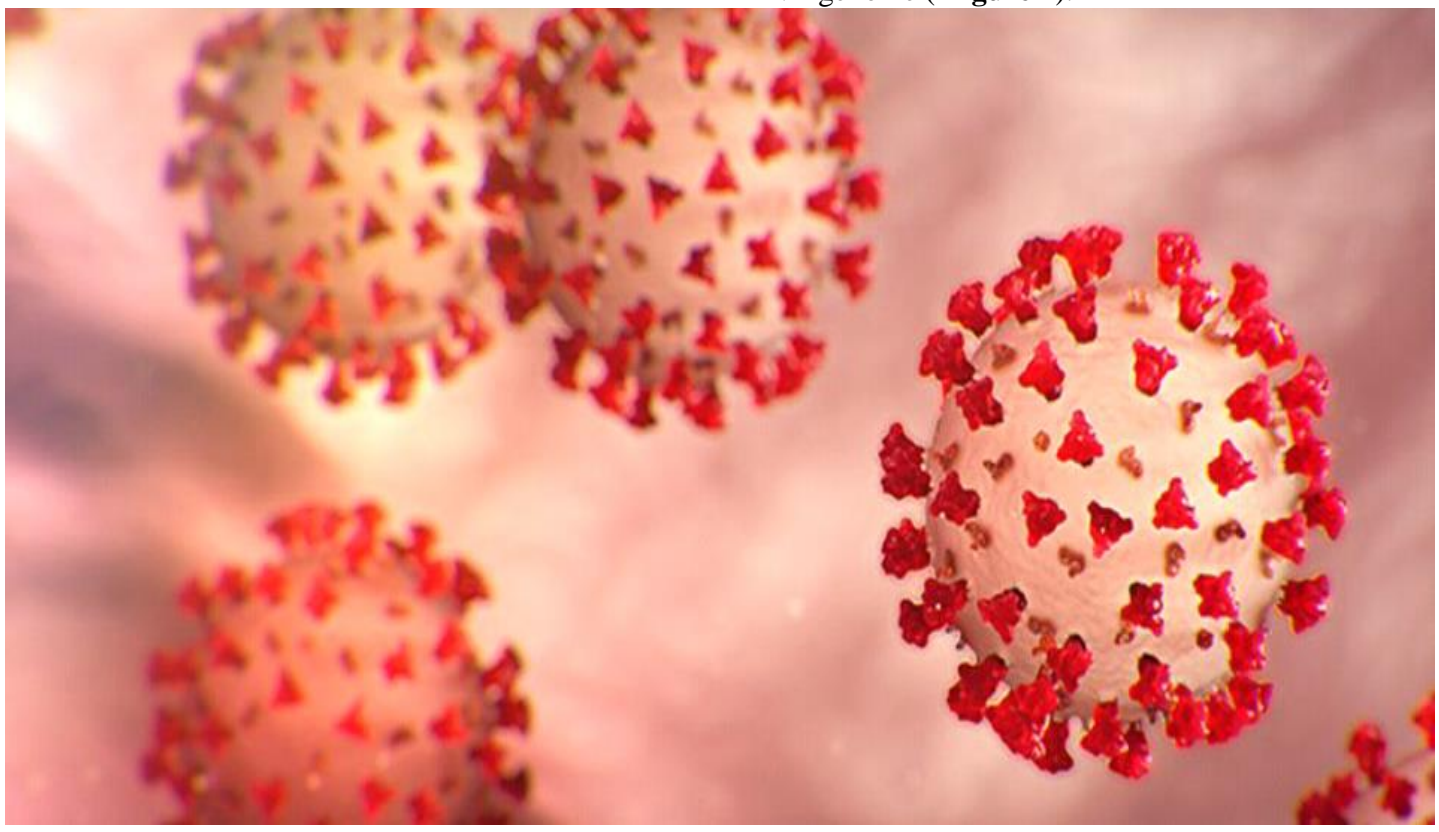


Acute Respiratory Syndrome (SARS) - CoV -2 is the name of a new disease caused by CoV disease and coronavirus disease 2019 (COVID19) Is a new threat to global health. The covid-19 epidemic began in late December 2019 in Wuhan, China, and then spread rapidly to Southeast Asian countries such as Thailand, Japan, Singapore, and even Iran. The virus has since spread rapidly around the world, including in Europe, such as Spain, Italy, and the United Kingdom, and the United States, and the United Arab Emirates. Outbreaks of covid-19 have been reported by the World Health Organization as a pandemic. The main symptoms of COVID-19 that Involve a person include fatigue, cough, fever, and lower respiratory tract infection signs. The coronaviridae family contains enveloped viruses, positive-strand RNA that are divided into four genera: $\alpha, \beta$ and $\gamma$ and also $\delta$. Six coronaviruses in the to disease in humans., including 229E and NL63 of the $\alpha$ genus

and OC43, HKU1, SARS-CoV, and MERS-CoV of the $\beta$ genus. Human coronavirus (hCoV) infection Involves the respiratory, nervous systems, and intestinal. The epidemic of severe acute respiratory diseases that occurred in China in 2002-2003 was caused by SARS-CoV-2. MERS-
CoV was discovered in 2012 in the Middle East. Both of these coronaviruses are pathogens that infect humans and lead to severe respiratory diseases, Which Possible Develop into severe acute respiratory distress syndrome. According to the experiment by Peng et al. COVID-19 uses the ACE2 receptor as a receptor to enter the cell (Figure 2); ACE2 is located on the trachea, epithelial cells of the alveoli, serious bronchial glands, bronchi, alveolar monocytes, and macrophages in the respiratory tract. In addition, ACE2 is greatly expressed on the mucosa, such as the lips and mouth, eyelids, nasal cavity. The pathogenic mechanism of COVID-19 is clear, as shown in Figure. 2. This virus enters the target cell through the

ACE2 receptor And then disseminate its single-stranded RNA (ssRNA) into the target cell Then composes with the ribosome in the target cell and is translated to RNA. The RNA replicas copy the ssRNA to produce negative-strand RNA, positive-strand RNA, and RNA fragments, which compose with the ribosome to produce a protein shell. The protein shell and the positive-strand RNA form the new SARS-CoV-2 virions, which are released to infect more target cells.

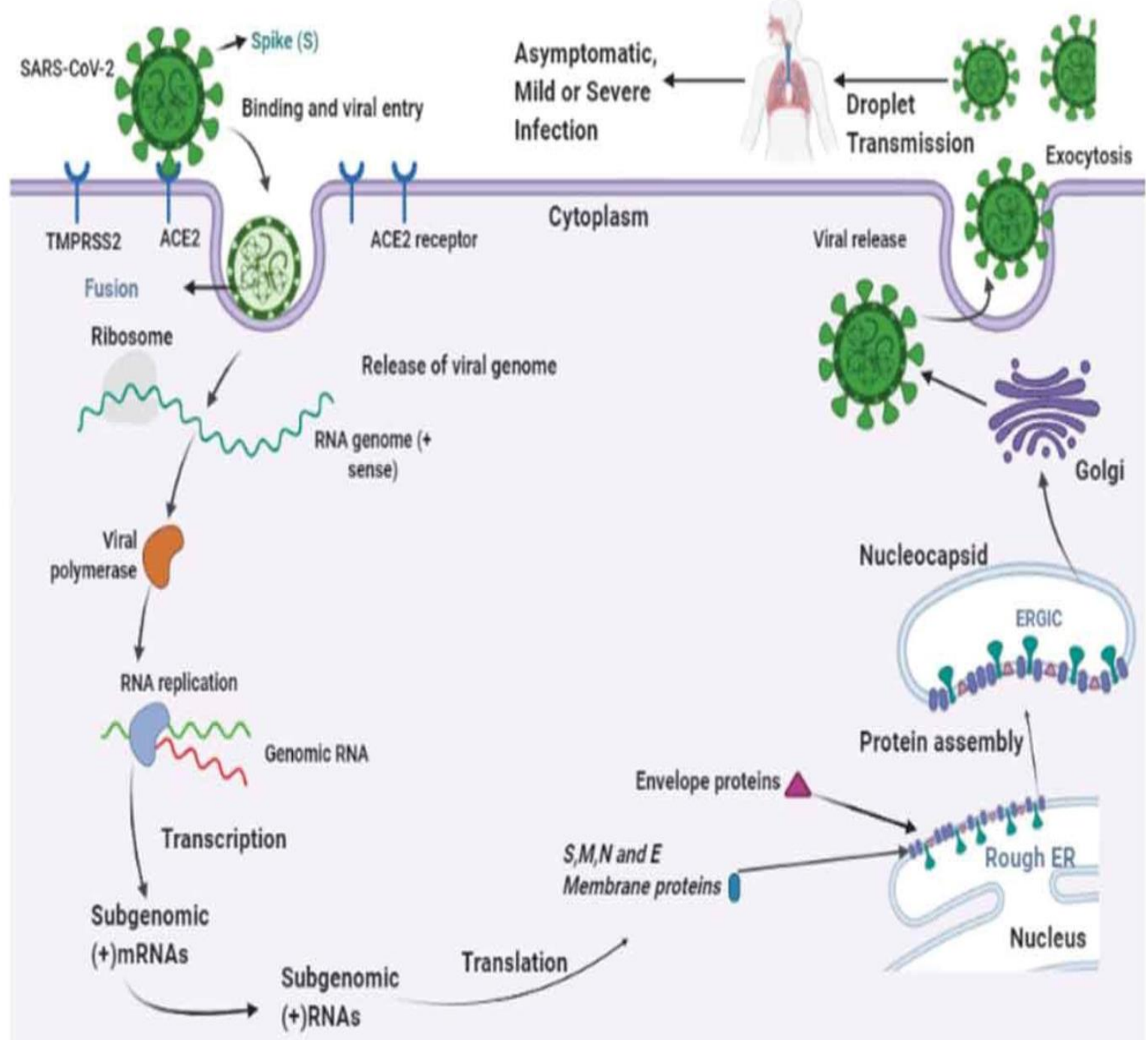

Figure 2: The transmission cycle of SARS-CoV-2 in the target cell. SARS-CoV-2 enters host cells by a membrane fusion or endosomal pathway. The $S$ protein of SARS-CoV-2 is connected to the ACE2 receptor in the target cell and enters into the target cell by viral fusion. The SARS-CoV-2 virus produces its RNA polymerase that synthesizes virus RNAS, this virus RNA transcribes smaller sub-genomic positive RNAs that are used to produce structural proteins. The proteins are completed in the membrane of the Endoplasmic Reticulum (ER) and are placed in a nucleocapsid, the progeny viruses are then released from the target cell through exocytosis by Golgi vesicles and are transferred by droplets causing infections. 


\section{Mutagenesis of covid-19 virus:}

Of course, it should be noted that among the RNA viruses, viruses with the segmented genome have the highest mutagenicity, such as the influenza virus, which belongs to the orthomyxoviridae family, which contains the segmented RNA genome. However, the mutagenicity of the Covid-19 virus is considered as an exception among RNA viruses that have a non-segmented genome. The only reason for the persistent mutagenesis of the covid-19 virus is that the Covid-19 virus can hide in the cells, where it fuses with the cell genome to produce a genome different from the genome that first entered the body, resulting in a mutation. Because some viruses can hide in the host cell and resume their activity immediately after the weakening of the immune system. The Covid-19 virus, like these viruses, can hide in the host cell, and after combining with part of the host cell genome, mutations occur in the virus.
It should be noted that this mutagenicity has manifested itself in people with weak immune systems and they do not necessarily have to travel to the rest of the world to catch it.

\section{Morphine :}

Morphine is one of the best candidates for Covid-19 virus treatment because morphine eliminates most of the symptoms caused by the Covid19 virus ( Figure 3 ). Friedrich Sertner, a German pharmacist, was the first to isolate Morphine between 1803 and 1805. It is thought to be the first isolation of an active ingredient from a plant. Morphine was marketed in 1827 by Merck. Morphine use increased dramatically between 1853-1855 after the Innovation of the hypodermic syringe. Sertürner named the substance morphium from the Greek god of dreams, Morpheus Because it creates a desire to sleep.

\section{Morphine}

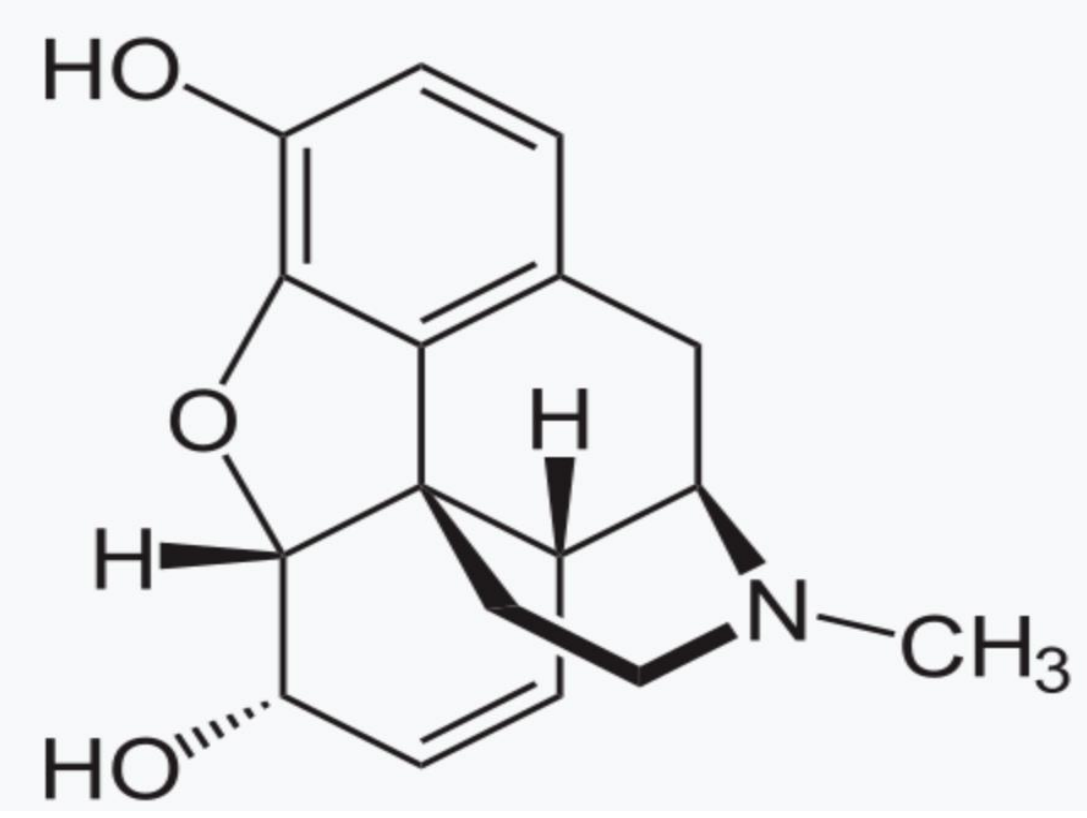

Figure 3: Chemical structure of morphine.

Initially, morphine has applications for treating acute and chronic severe pain. The duration of morphine analgesia is about 3 to 7 hours. Sideeffects of constipation and nausea are infrequently lead to stop treatment. It has applications for pain due to labor pains and myocardial infarction. So, there are concerns that morphine Likely increases mortality in the event of non-ST elevation myocardial infarction. Morphine has applications for acute pulmonary edema. Morphine is also used to reduce the sign of shortness of breath Caused by cancer and non-cancerous. In the Conditions of breathlessness at Relaxation or on at least Pressure from conditions such as advanced cancer or end-stage cardiorespiratory diseases, regular, low-dose sustained-release morphine dramatically reduces breathlessness safely, with its benefits maintained over time. Morphine activates the mu-opioid receptor(MOR) ( Figure 4 ). mu receptors are present in the medial thalamus and brainstem. Mu receptors are responsible for respiratory depression, supraspinal analgesia, sedation, euphoria, decreased gastrointestinal motility, and physical dependence. 


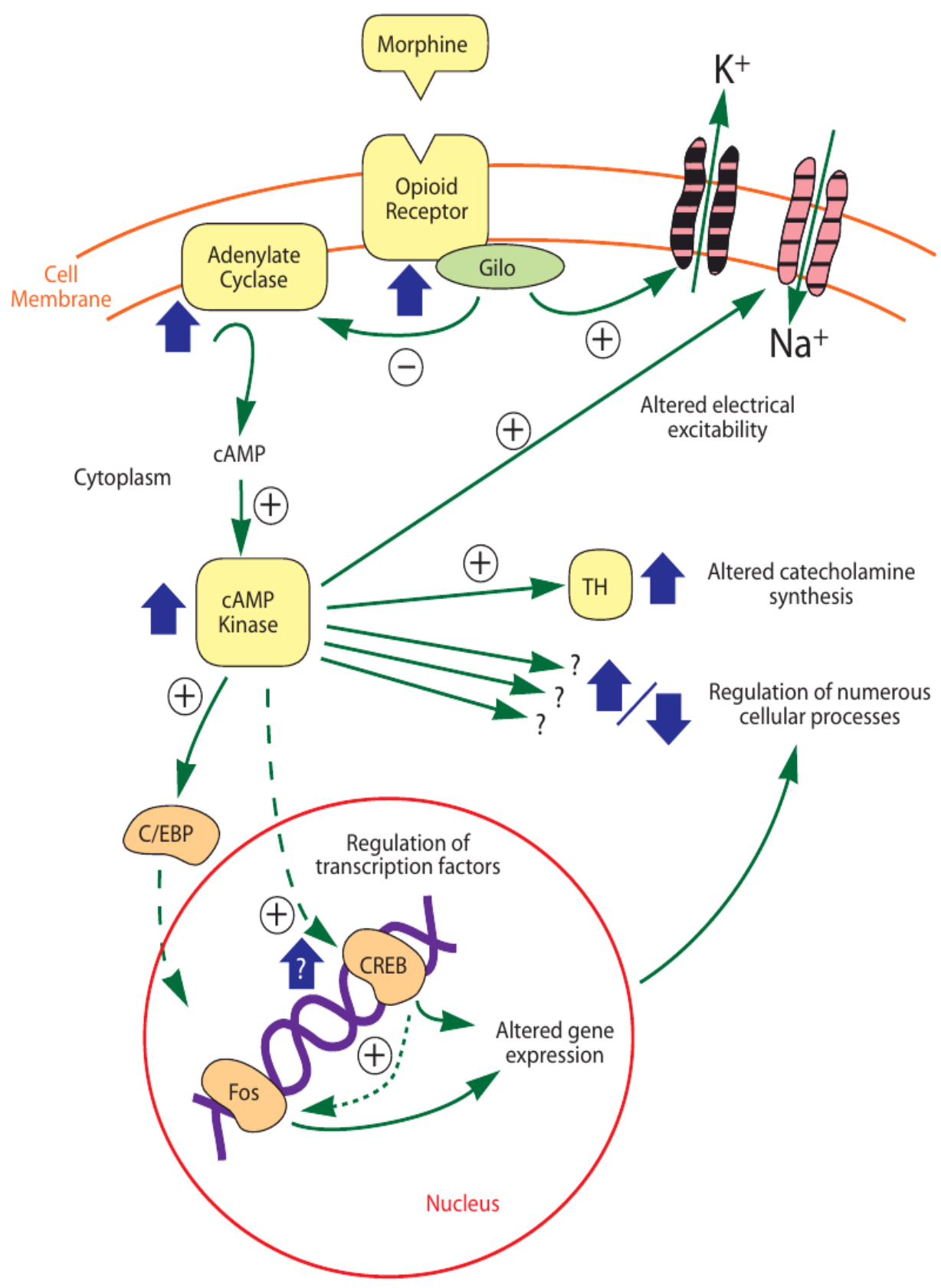

Figure 4: Intracellular morphine activation

Scientists have lately discovered that immunocytes contain specific receptors for morphine, They can bind to morphine and some opiate alkaloids, but in principle with no or very low desire for the naturally occurring endogenous opioid peptides or peptide analogs. The mu 3 receptor exists in invertebrate immunocytes and even in human peripheral blood monocytes such as macrophages. Lately, the mu 3 receptor has been Discovered in defined macrophage cell lines and human peripheral blood granulocytes. lastly, mu 3, a receptor similar or close relationship opiate alkaloid-selecting has been characterized to exist in neuroblastoma and the neuronal hybrid cell line. Recent studies have shown that immune cells receptor mediates between the inhibitory efficacy of morphine and cellular chemotaxis. In vivo Prescribed of morphine has been indicated to reduce the delayed-type hypersensitivity reaction, antibody production,
T-cell antigen expression, cytotoxic T-cell activity, neutrophil activity, and NK cell activity. While the functional binding of this receptor in neurons is unclear, it is hypothesized that the receptor might be mediating the effects of opioids on nerve Distinction and cell division as well as neurotransmission. Mu 3 receptor for the nervous and immune system might be the original location of Activity for endogenous morphine or morphine-like Materials. In addition, the mu 3 receptor supplies an extra Medicinal location for that are exogenously Prescribed opioid alkaloids drugs. Also, the mu 3 receptor is suggested to be a significant neuroimmune linkage. This system may perform an important role in types of Reactions Regarding the immune system, including the Reaction of the organism to stress, infection, and malignant Conversion. 


\section{Conclusion :}

By taking morphine, we find that it neutralizes at least 4 to 5 of the symptoms of Covid 19, including severe cough, severe pain, chronic diarrhea, and even stress if the person has Covid 19. It is also used in the treatment of acute pulmonary edema and reduces the symptoms of shortness of breath due to the covid-19 virus. Infection with the covid-19 virus increases heart rate and respiration rate than with morphine, not only do the symptoms listed above go away, but there is also a relative calm that slows the heart rate and, most importantly, reduces the rate of respiration. Morphine creates a competitive environment with the virus. The slower the rate of respiration and blood flow, the more immune cells can detect it. It should be noted that people who survive Covid 19 have a higher level of relaxation because our immune system can detect the virus by reducing Blood flow velocity and people who are unable to do so are prescribed morphine will do this for them. Because morphine has a high percentage of addiction, it should not be used more than twice. Also, in older people with weakened immune systems, in addition to morphine, it should be given from the serum of people rescued from Covid 19, which contains antibodies.

\section{Abbreviation:}

1. CoV: Coronavirus

2. HCoV: Human coronavirus

3. ssRNA: single-strand RNA

4. ACE2: angiotensin-converting enzyme 2

5. ER: Endoplasmic Reticulum

6. MOR: mu-opioid receptor

7. cAMP: cyclic AMP

Ethics approval and consent to participate :

Not applicable.

\section{Consent to publication :}

This manuscript is published with the aim that the Covid-19 virus is transmitted rapidly in the world and we are looking for a treatment for this disease.

\section{Availability of data and materials :}

The comments made in this article are purely the opinion of the author and so far no experiments have been performed on either humans or animals.

\section{Competing interests :}

The author declares no competing interests.

\section{Funding :}

Not applicable.

\section{Authors' contributions :}

Not applicable.

\section{Acknowledgments:}

I thank Maedeh Khanifar for helping me write this article.

\section{References:}

1. Umakanthan S, Sahu P, Ranade AV, Bukelo MM, Rao JS, Abrahao-Machado LF, Dahal S, Kumar H, Kv D. Origin, transmission, diagnosis and management of coronavirus disease 2019 (COVID-19). Postgrad Med J. 2020 Dec;96(1142):753-758. doi: 10.1136/postgradmedj-2020138234. Epub 2020 Jun 20. PMID: 32563999.

2. Habas K, Nganwuchu C, Shahzad F, Gopalan R, Haque M, Rahman S, Majumder AA, Nasim T. Resolution of coronavirus disease 2019 (COVID-19). Expert Rev Anti Infect Ther. 2020 Dec;18(12):1201-1211. doi: 10.1080/14787210.2020.1797487. Epub 2020 Aug 4. PMID: 32749914.

3. Zhang XY, Huang HJ, Zhuang DL, Nasser MI, Yang MH, Zhu $\mathrm{P}$, Zhao MY. Biological, clinical and epidemiological features of COVID-19, SARS and MERS and AutoDock simulation of ACE2. Infect Dis Poverty. 2020 Jul 20;9(1):99. doi: 10.1186/s40249-020-00691-6. PMID: 32690096; PMCID: PMC7369569.

4. Courtwright DT (2009). Forces of habit drugs and the making of the modern world (1 ed.). Cambridge, Mass.: Harvard University Press. pp. 36-37. ISBN 978-0-674-02990-3. Archived from the original on 8 September 2017.

5. Luch A, ed. (2009). Molecular, clinical and environmental toxicology. Springer. p. 20. ISBN 978-3-7643-8335-0.

6. Mosher CJ (2013). Drugs and Drug Policy: The Control of Consciousness Alteration. SAGE Publications. p. 123. ISBN 978-1-4833-2188-2. Archived from the original on 8 September 2017.

7. Fisher GL (2009). Encyclopedia of substance abuse prevention, treatment, \& recovery. Los Angeles: SAGE. p. 564. ISBN 9781-4522-6601-5. Archived from the original on 8 September 2017.

8. "Morphine sulfate". The American Society of Health-System Pharmacists. Archived from the original on 2 May 2015. Retrieved 1 June 2015.

9. Rockwood CA (2009). Rockwood and Wilkins' fractures in children (7th ed.). Philadelphia, Pa.: Lippincott Williams \& Wilkins. p. 54. ISBN 978-1-58255-784-787. Archived from the original on 8 September 2017.

10. "Morphine Sulfate". The American Society of Health-System Pharmacists. Archived from the original on 3 March 2011. Retrieved 3 April 2011.

11. Meine TJ, Roe MT, Chen AY, Patel MR, Washam JB, Ohman EM, et al. (June 2005). "Association of intravenous morphine use and outcomes in acute coronary syndromes: results from the CRUSADE Quality Improvement Initiative". American Heart Journal. 149 (6): 1043-1049. doi:10.1016/j.ahj.2005.02.010. PMID 15976786.

12. Schrijvers D, van Fraeyenhove F (2010). "Emergencies in palliative care". Cancer Journal. 16 (5): 514-20. doi:10.1097/PPO.0b013e3181f28a8d. PMID 20890149.

13. Naqvi F, Cervo F, Fields S (August 2009). "Evidence-based review of interventions to improve palliation of pain, dyspnea, depression". Geriatrics. 64 (8): 8-10, 12-14. PMID 20722311.

14. Parshall MB, Schwartzstein RM, Adams L, Banzett RB, Manning HL, Bourbeau J, et al. (February 2012). "An official American Thoracic Society statement: update on the mechanisms, assessment, and management of dyspnea". American Journal of Respiratory and Critical Care Medicine. 185 (4): 435-452. doi:10.1164/rccm.201111-2042ST. PMC 5448624. PMID 22336677.

15. Mahler DA, Selecky PA, Harrod CG, Benditt JO, CarrieriKohlman V, Curtis JR, et al. (March 2010). "American College of Chest Physicians consensus statement on the management of dyspnea in patients with advanced lung or heart disease". Chest. 137 (3): 674-91. doi:10.1378/chest.09-1543. PMID 20202949. S2CID 26739450. 
16. Trescot AM, Datta S, Lee M, Hansen H. Opioid pharmacology. Pain Physician. 2008 Mar;11(2 Suppl): S133-153. PMID: 18443637.

17. Chao, PK., Chang, HF., Ou, LC. et al. Convallatoxin enhance the ligand-induced mu-opioid receptor endocytosis and attenuate morphine antinociceptive tolerance in mice. Sci Rep 9, 2405 (2019).
18. Makman MH. Morphine receptors in immunocytes and neurons. Adv Neuroimmunol. 1994;4(2):69-82. doi: 10.1016/s0960-5428(05)80002-6. PMID: 7952830.

19. Hudzik B, Nowak J, Zubelewicz-Szkodzinska B. Consideration of immunomodulatory actions of morphine in COVID-19 Short report. Eur Rev Med Pharmacol Sci. 2020 Dec;24(24):13062-13064. 10.26355/eurrev_202012_24213. PMID: 33378059.
This work is licensed under Creative Commons Attribution 4.0 License
Submit Manuscript

DOI: $10.31579 / 2637-8876 / 022$
Ready to submit your research? Choose Auctores and benefit from:

$>$ fast, convenient online submission

$>$ rigorous peer review by experienced research in your field

$>$ rapid publication on acceptance

$>$ authors retain copyrights

$>$ unique DOI for all articles

$>$ immediate, unrestricted online access

At Auctores, research is always in progress.

Learn more https://auctoresonline.org/journals/immunology-andinflammation-diseases-therapy- 